\title{
Risk Factor and Mortality in Patients with Pulmonary Embolism Combined with Infectious Disease
}

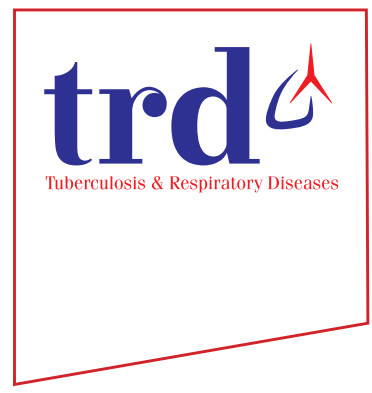

Gi Dong Lee, M.D. ${ }^{1}{ }^{(\mathbb{0}}$, Sunmi Ju, M.D. ${ }^{2}$, Ju-Young Kim, M.D. ${ }^{3}$, Tae Hoon Kim, M.D., Ph.D. ${ }^{3}$, Jung-Wan Yoo, M.D. ${ }^{2}$, Seung Jun Lee, M.D., Ph.D. ${ }^{2}$, Yu Ji Cho, M.D., Ph.D. ${ }^{2}$, Yi Yeong Jeong, M.D., Ph.D. ${ }^{2}$, Kyung Nyeo Jeon, M.D. Ph.D. ${ }^{4}$, Jong Deog Lee, M.D., Ph.D. ${ }^{2}$ and Ho Cheol Kim, M.D., Ph.D. ${ }^{3}$ (D)

${ }^{1}$ Department of Internal Medicine, Saint Carollo Hospital, Suncheon, ${ }^{2}$ Department of Internal Medicine, Gyeongsang National University Hospital, Gyeongsang National University School of Medicine, Jinju, Departments of ${ }^{3}$ Internal Medicine and ${ }^{4}$ Diagnostic Radiology, Gyeongsang National University Changwon Hospital, Gyeongsang National University School of Medicine, Changwon, Korea

Background: Infectious conditions may increase the risk of venous thromboembolism. The purpose of this study was to evaluate the risk factor for combined infectious disease and its influence on mortality in patients with pulmonary embolism (PE).

Methods: Patients with PE diagnosed based on spiral computed tomography findings of the chest were retrospectively analyzed. They were classified into two groups: patients who developed PE in the setting of infectious disease or those with PE without infection based on review of their medical charts.

Results: Of 258 patients with PE, 67 (25.9\%) were considered as having PE combined with infectious disease. The sites of infections were the respiratory tract in 52 patients (77.6\%), genitourinary tract in three patients (4.5\%), and hepatobiliary tract in three patients (4.5\%). Underlying lung disease (odds ratio [OR], 3.69; 95\% confidence interval [CI], 1.926-7.081; $\mathrm{p}<0.001$ ), bed-ridden state (OR, 2.84; 95\% CI, 1.390-5.811; $\mathrm{p}=0.004$ ), and malignant disease (OR, 1.867; 95\% CI, 1.0173.425; $\mathrm{p}=0.044$ ) were associated with combined infectious disease in patients with PE. In-hospital mortality was higher in patients with PE combined with infectious disease than in those with PE without infection (24.6\% vs. 11.0\%, $\mathrm{p}=0.006)$. In the multivariate analysis, combined infectious disease (OR, 4.189; 95\% CI, 1.692-10.372; $\mathrm{p}=0.002)$ were associated with non-survivors in patients with PE.

Conclusion: A substantial portion of patients with PE has concomitant infectious disease and it may contribute a mortality in patients with PE.

Keywords: Pulmonary Embolism; Infectious Disease; Mortality

Address for correspondence: Ho Cheol Kim, M.D., Ph.D.

Department of Internal Medicine, Gyeongsang National University Changwon Hospital, Gyeongsang National University School of Medicine, 11

Samjeongja-ro, Seongsan-gu, Changwon 51472, Korea

Phone: 82-55-214-3730, Fax: 82-55-214-8618, E-mail: hockkim@gnu.ac.kr

Received: May. 2, 2019, Revised: Aug. 24, 2019, Accepted: Jan. 21, 2020, Published online: Mar. 10, 2020

@(c) it is identical to the Creative Commons Attribution Non-Commercial License (http://creativecommons.org/licenses/by-nc/4.0/) 


\section{Introduction}

Venous thromboembolism (VTE), including deep vein thrombosis (DVT) and pulmonary embolism (PE), is a frequently overlooked, serious disorder ${ }^{1}$. Its incidence is increasing according to recent reports in western countries and in Korea $^{2-4}$.

There are various well-defined risk factors of VTE, including recent major surgery, immobilization, cancer, old age, obesity, use of oral contraceptives, hormonal factors, a previous history of thrombosis, and inherited risk factors ${ }^{5,6}$. In addition to known risk factors, infectious disease and the associated systemic inflammatory response may increase thrombotic events of the venous system ${ }^{7,8}$ caused by one or more of the three precipitants of venous thrombosis, as proposed by Virchow: venous stasis, hypercoagulability, and endothelial damage $^{9,10}$. Several reports have documented that the risk of VTE was increased in patients with certain infectious conditions, such as cytomegalovirus, Chlamydia pneumoniae, human immunodeficiency virus (HIV), hepatitis C virus infection, and a recent respiratory tract infection ${ }^{11-18}$. Despite several reports of recent infection and VTE, its independent relationship is unclear, and clinical data regarding PE combined with infectious conditions are lacking. Therefore, the aim of the study was to evaluate the clinical characteristics and source of infection in patients with PE combined with infectious disease. And, the risk factor associated with combined infectious disease and its influence on mortality in patients with PE were assessed.

\section{Materials and Methods}

\section{Study design and population}

Patients with PE found on computed tomography (CT) within 48 hours after admission were enrolled in this study. The study was conducted at regional university affiliated hospital (890 beds) between September 2010 and May 2014. Patients were excluded if they were admitted for pregnancy, preexisting PE or DVT, or were $<18$ years of age. The diagnosis of PE was confirmed based on chest findings obtained using a 64-detector CT, including enhanced CT and CT pulmonary angiogram, scanner (Brilliance-64; Philips Medical Systems, Eindhoven, Netherlands). A pulmonary radiologist assessed the existence of thrombosis in the pulmonary artery. This study was approved by the hospital's institutional review board (No. GNUCH-2018-07-001). The need for informed consent was waived because of the retrospective nature of the study.

\section{Data collection and clinical outcomes}

We retrospectively investigated patients' demographics, physiologic data, and laboratory data and the causes of infec-
Table 1. Clinical characteristics of enrolled patients with PE

\begin{tabular}{|c|c|}
\hline Clinical characteristic & Value $(n=258)$ \\
\hline \multicolumn{2}{|l|}{ Demographics } \\
\hline Age, yr & $68.2 \pm 13.0$ \\
\hline Age $>65 \mathrm{yr}$ & $171(66.3)$ \\
\hline Male sex & $143(55.4)$ \\
\hline BMI (n=233) & $22.76 \pm 3.9$ \\
\hline $\mathrm{BMI}>30 \mathrm{~kg} / \mathrm{m}^{2}$ & $13(5.0)$ \\
\hline Current smoking history & $17(6.5)$ \\
\hline \multicolumn{2}{|l|}{ Clinical symptoms and signs } \\
\hline Dyspnea & $155(60.0)$ \\
\hline Hemoptysis & $10(3.8)$ \\
\hline Fever & $24(9.3)$ \\
\hline Chest pain & $37(14.3)$ \\
\hline Lower leg edema & $29(11.2)$ \\
\hline Syncope & $3(1.2)$ \\
\hline Hypotension & $15(5.8)$ \\
\hline Asymptomatic & $70(27.1)$ \\
\hline Revised Geneva score & $6.0 \pm 1.6$ \\
\hline Died & $37(14.3)$ \\
\hline \multicolumn{2}{|l|}{ Risk factors } \\
\hline History of recent operation ( $<3$ mo) & $67(25.9)$ \\
\hline Previous history of VTE & $20(7.7)$ \\
\hline Presence of infectious disease & $67(25.9)$ \\
\hline Bed-ridden state & $51(19.7)$ \\
\hline \multicolumn{2}{|l|}{ Comorbidities } \\
\hline Malignant disease & $145(56.2)$ \\
\hline Cerebrovascular disease & $30(11.6)$ \\
\hline Lung disease & $64(24.8)$ \\
\hline Heart disease & $9(3.5)$ \\
\hline Liver disease & $14(5.4)$ \\
\hline Kidney disease & $8(3.1)$ \\
\hline Diabetes & $56(21.7)$ \\
\hline Hypertension & $85(32.9)$ \\
\hline Autoimmune disease & $3(1.2)$ \\
\hline \multicolumn{2}{|l|}{ Laboratory findings } \\
\hline $\mathrm{WBC}, \mathrm{mm}^{3} / \mathrm{L}$ & $10.6 \pm 27.8$ \\
\hline Platelet, $\mathrm{mm}^{3} / \mathrm{L}$ & $239.2 \pm 111.5$ \\
\hline $\mathrm{CRP}, \mathrm{mg} / \mathrm{L}$ & $51.1 \pm 62.7$ \\
\hline D-dimer, $\mu \mathrm{g} / \mathrm{mL}(\mathrm{n}=195)$ & $6.6 \pm 6.3$ \\
\hline BNP, pg/mL (n=147) & $332.7 \pm 440.0$ \\
\hline Troponin-I, ng/mL (n=155) & $1.0 \pm 9.1$ \\
\hline CK-MB (n=158) & $3.5 \pm 3.8$ \\
\hline
\end{tabular}


Table 1. Continued

\begin{tabular}{|lc|}
\hline \multicolumn{1}{|c|}{ Clinical characteristic } & Value (n=258) \\
\hline Fibrinogen, $\mathrm{mg} / \mathrm{dL}(\mathrm{n}=138)$ & $393.4 \pm 165.7$ \\
\hline AT III, $\mathrm{mg} / \mathrm{dL}(\mathrm{n}=89)$ & $89.4 \pm 39.4$ \\
\hline Homocysteine, $\mu$ mol/L $(\mathrm{n}=41)$ & $9.3 \pm 5.6$ \\
\hline Radiologic findings & $121(46.8)$ \\
\hline Norma chest X-ray & \\
\hline Involvement of pulmonary artery on chest CT & $52(20.2)$ \\
\hline Main pulmonary artery, right & $39(15.1)$ \\
\hline Main pulmonary artery, left & $103(39.9)$ \\
\hline Interlobar artery, right & $69(26.7)$ \\
\hline Interlobar artery, left & $158(61.2)$ \\
\hline Segmental artery, right & $95(36.8)$ \\
\hline Segmental artery, left & $88(34.1)$ \\
\hline Subsegmental artery, right & $51(19.7)$ \\
\hline Subsegmental artery, left & \\
\hline Echocardiographic finding $(\mathrm{n}=164)$ & $58(22.4)$ \\
\hline Pulmonary hypertension & $30(11.6)$ \\
\hline Right ventricular hypokinesia & \\
\hline
\end{tabular}

Values are presented as mean \pm SD or number $(\%)$.

BMI: body mass index; VTE: venous thromboembolism; WBC: white blood cell; CRP: C-reactive protein; BNP: B-type natriuretic peptide; CK-MB: creatine kinase-muscle/brain; AT: antithrombin; CT: computerized tomography.

tion, underlying diseases, and clinical outcomes. We divided patients into one of two groups based on information obtained from their medical charts: patients with PE combined with infectious disease or those with PE without infection. Patients' characteristics were compared between those two groups, and between survivors and non-survivors. Finally, we analyzed the risk factors associated with combined infectious disease in PE patients and compared mortality between those two groups. And we assessed the factor associated nonsurvivors in patients with $\mathrm{PE}$.

\section{Definition}

The definition of infection was based on microbiologic data and the patient's clinical course upon medical chart review. Infection was classified according to the Centers for Disease Control and Prevention's definitions ${ }^{19}$.

\section{Statistical analysis}

Continuous variables are reported as the mean \pm standard deviation. Categorical variables are expressed as a number (\%). Differences between the groups were statistically assessed
Table 2. The site and cause of infection in patients with pulmonary embolism combined with infectious disease

\begin{tabular}{|cc|}
\hline \multicolumn{1}{|c|}{ Cause of infection } & No. (\%) (n=67) \\
\hline Respiratory tract infection & $52(77.6)$ \\
Pneumonia & $44(65.6)$ \\
Acute bronchiolitis & $4(5.9)$ \\
Pulmonary tuberculosis & $4(5.9)$ \\
\hline Genitourinary tract infection & $3(4.4)$ \\
Hepatobiliary tract infection & $3(4.4)$ \\
Acute cholecystitis & $1(1.5)$ \\
Acute pancreatitis & $1(1.5)$ \\
\hline Perihepatic abscess & $1(1.5)$ \\
Gastrointestinal tract infection & $2(2.9)$ \\
\hline Ischemic colitis & $2(2.9)$ \\
Bone and joint infection & $3(4.4)$ \\
\hline Osteomyelitis of spine & $3(4.4)$ \\
Skin and soft tissue infection & $2(2.9)$ \\
\hline Shoulder abscess & $1(1.5)$ \\
Necrotizing fasciitis & $1(1.5)$ \\
Miscellaneous infection & $2(2.9)$ \\
Infective endocarditis & $1(1.5)$ \\
Tuberculous pericarditis & $1(1.5)$ \\
\hline
\end{tabular}

using Student's t test or the chi-square test, as appropriate. Univariate and multivariate logistic regression analyses were performed to examine the risk factors for the development of infectious disease and mortality. A p-value of $<0.05$ was considered statistically significant in all tests. All data were analyzed using SPSS version 22.0 for Window (IBM Corp., Armonk, NY, USA).

\section{Results}

\section{Patients' characteristics}

Two hundred fifty-eight patients (male:female, 143:115; mean age, $68.2 \pm 13.0$ years) were included. The most common symptom was dyspnea in up to $60 \%$ of patients, and 70 patients (26.9\%) were asymptomatic. Twenty patients $(7.7 \%)$ had a previous history of VTE, and 145 (55.8\%) had an underlying malignant disease. One hundred seventy-one patients (65.8\%) were older than 65 years, and 13 (5\%) had a body mass index more than $30 \mathrm{~kg} / \mathrm{m}^{2}$. Fifty-eight patients (22.3\%) showed echocardiographic evidence of pulmonary hypertension, such as right ventricular hypokinesia or an increased pulmonary arterial pressure more than $20 \mathrm{~mm} \mathrm{Hg}$. The main 
Table 3. Comparison of clinical characteristics in patients with PE combined with infectious disease and in patients with PE without infection

\begin{tabular}{|c|c|c|c|}
\hline Variable & $\begin{array}{c}\text { Combined with infectious } \\
\text { disease }(n=67)\end{array}$ & $\begin{array}{l}\text { Not combined with } \\
\text { infection }(n=191)\end{array}$ & p-value \\
\hline \multicolumn{4}{|l|}{ Demographics } \\
\hline Age, yr & $71.6 \pm 12.2$ & $67.2 \pm 13.2$ & 0.028 \\
\hline Age $>65 \mathrm{yr}$ & $52(77.6)$ & $119(62.3)$ & 0.018 \\
\hline Male sex & $21(31.3)$ & $122(63.9)$ & 0.972 \\
\hline BMI (n=233) & $21.8 \pm 4.2$ & $23.1 \pm 3.7$ & 0.053 \\
\hline $\mathrm{BMI}>30 \mathrm{~kg} / \mathrm{m}^{2}$ & $4(6.0)$ & $9(4.7)$ & 0.458 \\
\hline Current smoking history & $1(1.5)$ & $16(8.3)$ & 0.208 \\
\hline \multicolumn{4}{|l|}{ Clinical symptoms and signs } \\
\hline Dyspnea & $51(76.1)$ & $104(54.4)$ & 0.002 \\
\hline Hemoptysis & $4(6.0)$ & $6(3.1)$ & 0.294 \\
\hline Fever & $12(17.9)$ & $12(6.2)$ & 0.004 \\
\hline Chest pain & $7(10.4)$ & $30(15.7)$ & 0.304 \\
\hline Lower leg edema & $7(10.4)$ & $22(11.5)$ & 0.831 \\
\hline Syncope & $0(0)$ & $3(1.6)$ & 0.305 \\
\hline Hypotension & $3(4.5)$ & $12(6.2)$ & 0.599 \\
\hline Asymptomatic & $15(22.4)$ & $55(28.8)$ & 0.331 \\
\hline Revised Geneva score & $5.9 \pm 1.6$ & $6.1 \pm 1.5$ & 0.302 \\
\hline Died & $15(22.4)$ & $22(11.5)$ & 0.027 \\
\hline \multicolumn{4}{|l|}{ Risk factors } \\
\hline History of recent operation (<3 mo) & $7(10.4)$ & $20(10.4)$ & 0.458 \\
\hline Previous history of VTE & $5(7.5)$ & $15(7.8)$ & 0.497 \\
\hline Bed-ridden state & $21(31.3)$ & $30(15.7)$ & 0.001 \\
\hline \multicolumn{4}{|l|}{ Comorbidities } \\
\hline Malignant disease & $27(40.3)$ & $98(51.3)$ & 0.343 \\
\hline Cerebrovascular disease & $12(17.9)$ & $18(9.4)$ & 0.012 \\
\hline Lung disease & $39(58.2)$ & $25(13.1)$ & 0.001 \\
\hline Heart disease & $9(13.4)$ & $29(15.1)$ & 0.103 \\
\hline Liver disease & $5(7.5)$ & $9(4.7)$ & 0.451 \\
\hline Kidney disease & $3(4.5)$ & $6(3.1)$ & 0.454 \\
\hline Diabetes & $12(17.9)$ & $44(23.0)$ & 0.402 \\
\hline Hypertension & $16(23.9)$ & $69(36.1)$ & 0.074 \\
\hline Autoimmune disease & $2(3.0)$ & $1(0.5)$ & 0.164 \\
\hline \multicolumn{4}{|l|}{ Laboratory findings } \\
\hline $\mathrm{WBC}, \mathrm{mm}^{3} / \mathrm{L}$ & $16.4 \pm 54.0$ & $8.6 \pm 5.4$ & 0.048 \\
\hline Platelet, $\mathrm{mm}^{3} / \mathrm{L}$ & $269.3 \pm 115.4$ & $228.7 \pm 108.4$ & 0.013 \\
\hline $\mathrm{CRP}, \mathrm{mg} / \mathrm{L}$ & $69.1 \pm 63.0$ & $44.9 \pm 61.7$ & 0.008 \\
\hline D-dimer, $\mu \mathrm{g} / \mathrm{mL}(\mathrm{n}=195)$ & $5.9 \pm 5.9$ & $6.9 \pm 6.5$ & 0.299 \\
\hline BNP, pg/mL $(\mathrm{n}=147)$ & $445.8 \pm 543.7$ & $275.0 \pm 366.3$ & 0.025 \\
\hline Troponin-I, ng/mL (n=155) & $0.3 \pm 1.2$ & $1.3 \pm 11.0$ & 0.521 \\
\hline CK-MB $(\mathrm{n}=158)$ & $3.9 \pm 4.4$ & $3.4 \pm 3.6$ & 0.496 \\
\hline
\end{tabular}


Table 3. Continued

\begin{tabular}{|c|c|c|c|}
\hline Variable & $\begin{array}{c}\text { Combined with infectious } \\
\text { disease }(n=67)\end{array}$ & $\begin{array}{l}\text { Not combined with } \\
\text { infection }(n=191)\end{array}$ & p-value \\
\hline Fibrinogen, mg/dL (n=138) & $435.6 \pm 190.1$ & $380.7 \pm 156.5$ & 0.143 \\
\hline AT III, mg/dL (n=89) & $79.8 \pm 23.2$ & $92.1 \pm 42.5$ & 0.099 \\
\hline Homocysteine, $\mu \mathrm{mol} / \mathrm{L}(\mathrm{n}=41)$ & $6.5 \pm 3.6$ & $10.1 \pm 5.9$ & 0.042 \\
\hline \multicolumn{4}{|l|}{ Radiologic findings } \\
\hline Norma chest X-ray & $22(32.8)$ & $99(51.8)$ & 0.009 \\
\hline Main pulmonary artery involvement & $15(22.4)$ & $54(28.3)$ & 0.372 \\
\hline Isolated segmental or subsegmental artery involvement & $37(55.2)$ & $94(49.2)$ & 0.358 \\
\hline \multicolumn{4}{|l|}{ Echocardiographic finding $(\mathrm{n}=164)$} \\
\hline Pulmonary hypertension & $17(25.4)$ & $41(21.4)$ & 0.484 \\
\hline Right ventricular hypokinesia & $6(9.0)$ & $24(12.5)$ & 0.442 \\
\hline
\end{tabular}

Values are presented as mean \pm SD or number (\%).

PE: pulmonary embolism; BMI: body mass index; VTE: venous thromboembolism; WBC: white blood cell; CRP: C-reactive protein; BNP: Btype natriuretic peptide; CK-MB: creatine kinase-muscle/brain; AT: antithrombin.

Table 4. Factor associated with infectious disease in patients with PE

\begin{tabular}{|c|c|c|c|c|c|c|}
\hline \multirow{2}{*}{ Variable } & \multicolumn{3}{|c|}{ Univariate analysis } & \multicolumn{3}{|c|}{ Multivariate analysis } \\
\hline & OR & $95 \%$ CI & p-value & OR & $95 \%$ CI & p-value \\
\hline Age $>65 \mathrm{yr}$ & 2.15 & $1.133-4.103$ & 0.019 & 1.922 & $0.977-3.779$ & 0.058 \\
\hline $\mathrm{BMI}>30 \mathrm{~kg} / \mathrm{m}^{2}$ & 1.27 & $0.378-4.268$ & 0.699 & - & - & - \\
\hline Bed-ridden state & 2.48 & $1.299-4.735$ & 0.006 & 2.842 & $1.390-5.811$ & 0.004 \\
\hline Lung disease & 3.44 & $1.879-6.317$ & $<0.001$ & 3.693 & $1.926-7.081$ & 0.000 \\
\hline Cerebrovascular disease & 2.12 & $0.964-4.672$ & 0.062 & - & - & - \\
\hline Malignant disease & 2.331 & $1.321-4.111$ & 0.003 & 1.867 & $1.017-3.425$ & 0.044 \\
\hline Kidney disease & 1.043 & $0.205-5.296$ & 0.960 & - & - & - \\
\hline Liver disease & 1.649 & $0.532-5.106$ & 0.386 & - & - & - \\
\hline Diabetes & 1.353 & $0.666-2.751$ & 0.403 & - & - & - \\
\hline
\end{tabular}

PE: pulmonary embolism; OR: odds ratio; CI: confidence interval; BMI: body mass index.

pulmonary artery was involved in 88 patients (33.8\%) based on CT findings. Thirty-seven patients (14.2\%) died and the cause of death were underlying malignant disease in 27 patients (10.4\%), uncontrolled infectious disease with multiorgan failure in six patients (2.3\%), progression of underlying lung disease in three patients (1.1\%), and heart failure in one patient (Table 1). Overall, 67 patients $(25.9 \%)$ had a concomitant infectious disease. The infections involved the respiratory tract in 52 patients $(77.6 \%)$, genitourinary tract in three (4.5\%), hepatobiliary tract in three (4.5\%), gastrointestinal tract in two (2.98\%), bones and joints in three (4.5\%), and other organ systems in four (5.4\%) (Table 2).

\section{Comparison of clinical characteristics in PE patients with infectious disease and without infection}

The proportion of patients with dyspnea was greater among patients with PE combined with infectious disease than among those with PE without infection ( $76.1 \%$ vs. $53.9 \%$, $\mathrm{p}<0.05$ ). The frequency of fever was more common in patients with PE combined with infectious disease than in those with PE without infection ( $17.9 \%$ vs. $6.2 \%, p<0.05)$. The proportion of patients older than 65 years was higher among patients with PE combined with infectious disease than among those with PE without infection $(77.6 \%$ vs. $61.7 \%$, p $<0.05)$. The revised Geneva score $^{20}$ was not different between the two groups. The white blood cell count, serum C-reactive protein level, B-type natriuretic peptide level, and platelet count were significantly higher in patients with PE combined with infectious disease 
Table 5. Comparison of clinical characteristics between survivors and non-survivors in patients with PE

\begin{tabular}{|c|c|c|c|}
\hline Variable & Survivors $(\mathrm{n}=221)$ & Non-survivors $(\mathrm{n}=37)$ & p-value \\
\hline \multicolumn{4}{|l|}{ Demographics } \\
\hline Age, yr & $62.0 \pm 15.4$ & $69.3 \pm 12.3$ & 0.002 \\
\hline Male sex & $122(55.2)$ & $21(56.8)$ & 0.817 \\
\hline Age $>65 \mathrm{yr}$ & $155(70.1)$ & $16(43.2)$ & 0.002 \\
\hline BMI (n=233) & $22.8 \pm 3.9$ & $22.1 \pm 3.9$ & 0.333 \\
\hline BMI $>30 \mathrm{~kg} / \mathrm{m}^{2}$ & $12(5.4)$ & $1(2.7)$ & 0.552 \\
\hline Current smoking history & $17(7.6)$ & $0(0)$ & 0.316 \\
\hline \multicolumn{4}{|l|}{ Clinical symptoms and signs } \\
\hline Dyspnea & $129(58.3)$ & $26(70.3)$ & 0.154 \\
\hline Hemoptysis & $9(4.0)$ & $1(2.7)$ & 0.696 \\
\hline Fever & $19(8.5)$ & $5(13.5)$ & 0.331 \\
\hline Chest pain & $31(14.0)$ & $6(16.2)$ & 0.709 \\
\hline Lower leg edema & $19(8.5)$ & $10(27.0)$ & 0.001 \\
\hline Syncope & $3(1.3)$ & $0(0)$ & 0.478 \\
\hline Hypotension & $11(5.0)$ & $4(10.8)$ & 0.156 \\
\hline Asymptomatic & $63(28.5)$ & $7(18.9)$ & 0.236 \\
\hline Revised Geneva score & $6.0 \pm 1.5$ & $6.2 \pm 1.4$ & 0.655 \\
\hline \multicolumn{4}{|l|}{ Risk factors } \\
\hline History of recent operation $(<3$ mo $)$ & $22(9.9)$ & $2(5.4)$ & 0.458 \\
\hline Previous history of VTE & $15(6.8)$ & $5(13.2)$ & 0.186 \\
\hline Bed-ridden state & $38(17.1)$ & $13(35.1)$ & 0.010 \\
\hline \multicolumn{4}{|l|}{ Comorbidities } \\
\hline Malignant disease & $114(51.5)$ & $31(83.8)$ & $<0.001$ \\
\hline Cerebrovascular disease & $27(12.2)$ & $3(8.1)$ & 0.481 \\
\hline Lung disease & $53(23.9)$ & $11(29.7)$ & 0.436 \\
\hline Heart disease & $37(16.7)$ & $3(7.9)$ & 0.225 \\
\hline Liver disease & $12(5.4)$ & $2(5.4)$ & 0.995 \\
\hline Kidney disease & $5(2.2)$ & $3(8.1)$ & 0.454 \\
\hline Diabetes & $48(21.7)$ & $8(21.6)$ & 0.989 \\
\hline Hypertension & $70(31.6)$ & $15(40.5)$ & 0.272 \\
\hline Autoimmune disease & $3(1.3)$ & 0 & 0.478 \\
\hline Infectious disease & $52(23.5)$ & $15(40.5)$ & 0.027 \\
\hline \multicolumn{4}{|l|}{ Laboratory findings } \\
\hline $\mathrm{WBC}, \mathrm{mm}^{3} / \mathrm{L}$ & $10,521 \pm 3,001$ & $11,197 \pm 6,334$ & 0.765 \\
\hline Platelet, $\mathrm{mm}^{3} / \mathrm{L}$ & $244,257 \pm 11,322$ & $209,354 \pm 96,246$ & 0.052 \\
\hline $\mathrm{CRP}, \mathrm{mg} / \mathrm{L}$ & $48.3 \pm 62.8$ & $68.3 \pm 60.7$ & 0.073 \\
\hline D-dimer, $\mu \mathrm{g} / \mathrm{mL}(\mathrm{n}=195)$ & $6.69 \pm 6.29$ & $6.75 \pm 6.65$ & 0.964 \\
\hline BNP, pg/mL (n=147) & $317.5 \pm 431.4$ & $442.9 \pm 497.5$ & 0.320 \\
\hline Troponin-I, ng/mL (n=155) & $0.30 \pm 0.99$ & $5.3 \pm 24.28$ & 0.018 \\
\hline CK-MB (n=158) & $3.72 \pm 3.99$ & $2.54 \pm 2.57$ & 0.70 \\
\hline Fibrinogen, mg/dL (n=138) & $392.4 \pm 167.4$ & $398.59 \pm 160.7$ & 0.871 \\
\hline
\end{tabular}


Table 5. Continued

\begin{tabular}{|lccc|}
\hline \multicolumn{1}{|c}{ Variable } & Survivors $(\mathbf{n}=\mathbf{2 2 1})$ & Non-survivors $(\mathbf{n}=\mathbf{3 7})$ & p-value \\
\hline AT III, $\mathrm{mg} / \mathrm{dL}(\mathrm{n}=89)$ & $92.2 \pm 41.1$ & $73.61 \pm 22.4$ & 0.023 \\
\hline Homocysteine, $\mu \mathrm{mol} / \mathrm{L}(\mathrm{n}=41)$ & $9.4 \pm 5.7$ & $7.2 \pm 3.0$ & 0.476 \\
\hline Radiologic findings & & & \\
\hline Norma chest X-ray & $111(49.8)$ & $10(27.0)$ & 0.010 \\
\hline Main pulmonary artery involvement & $53(23.8)$ & $16(43.2)$ & 0.013 \\
\hline Isolated segmental or subsegmental artery involvement & $113(50.7)$ & $18(48.6)$ & 0.820 \\
\hline Echocardiographic finding (n=164) & & & 0.750 \\
\hline Pulmonary hypertension & $49(22.0)$ & $9(24.3)$ & 0.038 \\
\hline Right ventricular hypokinesia & $22(9.9)$ & $8(21.6)$ & \\
\hline
\end{tabular}

Values are presented as mean \pm SD or number (\%).

PE: pulmonary embolism; BMI: body mass index; VTE: venous thromboembolism; WBC: white blood cell; CRP: C-reactive protein; BNP: Btype natriuretic peptide; CK-MB: creatine kinase-muscle/brain; AT: antithrombin.

than in those with PE without underlying infection $(\mathrm{p}<0.05)$. The D-dimer level was not significantly different between two groups. The frequency of main pulmonary artery involvement based on CT findings was not different between PE patients with infectious disease and without infection (28\% and $22.4 \%$, respectively). The sole segmental or subsegmental pulmonary artery involvement was also not different between PE patients with infectious disease and without infection $(48.7 \%$ and $55.2 \%$, respectively). In-hospital mortality was higher in patients with PE combined with infectious disease than in those with PE without infection (22.4\% vs. 11.4\%, p=0.006) (Table 3).

\section{Factors associated with PE combined with infectious disease}

In multivariate analysis, the results showed that underlying lung disease (odds ratio [OR], 3.69; 95\% confidence interval [CI], 1.926-7.081; $\mathrm{p}<0.001$ ), bed-ridden state (OR, 2.84; 95\% CI, 1.390-5.811; $\mathrm{p}=0.004)$, and malignant disease (OR, 1.867; $95 \% \mathrm{CI}, 1.017-3.425 ; \mathrm{p}=0.044$ ) were associated with combined infectious disease in patients with PE (Table 4).

\section{Comparison of clinical characteristics between survivors and non-survivors in patients with $\mathrm{PE}$}

The clinical characteristics and laboratory findings were compared between survivors and non-survivors in patients with PE (Table 5). The mean age and proportion of patients older than 65 years were higher in non-survivors than in survivors $(\mathrm{p}<0.05)$. Clinical symptoms and signs were not different between the two groups. Bed-ridden state, underlying malignant and cerebrovascular diseases were more common in non-survivors than in survivors $(\mathrm{p}<0.05)$. Combined infectious diseases were also common in non-survivors than in survivors ( $44.7 \%$ vs. $23.4 \%, \mathrm{p}<0.05)$. The troponin-I were higher in non-survivors than in survivors $(\mathrm{p}<0.05)$. Radiologically, main pulmonary artery involvement was more common in non-survivors than in survivors ( $43.2 \%$ vs. $23.8 \%, \mathrm{p}<0.05$ ). Right ventricular hypokinesia detected by echocardiography was also more common in non-survivors than in survivors (21.6\% vs. $9.9 \%, \mathrm{p}<0.05)$.

\section{Factors associated with non-survivors in patients with PE}

In multivariate analysis, the result showed that age $>65$ years (OR, 2.575; 95\% CI, 1.125-5.892; $\mathrm{p}=0.025)$, bed-ridden state (OR, 3.487; 95\% CI, 1.397-8.703; $\mathrm{p}=0.007$ ), malignant disease (OR, 9.275; 95\% CI, 3.181-27.040; $\mathrm{p}<0.001$ ), main pulmonary artery involvement (OR, 3.032; 95\% CI, 1.283-7.162; $\mathrm{p}=0.011$ ), and concomitant infectious disease (OR, 4.189; 95\% CI, 1.692-10.372; $\mathrm{p}=0.002$ ) were associated with non-survivors in patients of $\mathrm{PE}$ (Table 6).

\section{Discussion}

This study showed that a substantial portion of patients with PE had concomitant infectious disease. The underlying lung disease, bed-ridden state and malignant disease were independent risk factor for PE with combined infectious disease and presence of infectious disease may contribute mortality in patients with $\mathrm{PE}$.

Several reports have shown that various infectious conditions were associated with the development of VTE, and overall, $11 \%-26 \%$ of patients with VTE may have an underlying acute infectious conditions $\mathrm{s}^{21-25}$. For example, cytomegalovirus antigen positivity was significantly higher in patients with VTE than in age-matched and sex-matched controls ${ }^{13}$. Additionally, in 312,147 patients with inflammatory bowel disease, 
Table 6. Factors associated with non-survivors in patients with PE

\begin{tabular}{|c|c|c|c|c|c|c|}
\hline \multirow{2}{*}{ Variable } & \multicolumn{3}{|c|}{ Univariate analysis } & \multicolumn{3}{|c|}{ Multivariate analysis } \\
\hline & OR & 95\% CI & p-value & OR & 95\% CI & p-value \\
\hline Age $>65 \mathrm{yr}$ & 2.992 & $1.471-6.086$ & 0.002 & 2.575 & $1.125-5.892$ & 0.025 \\
\hline $\mathrm{BMI}>30 \mathrm{~kg} / \mathrm{m}^{2}$ & 2.087 & $0.263-16.547$ & 0.486 & - & - & - \\
\hline Bed-ridden state & 2.637 & $1.233-5.638$ & 0.012 & 3.487 & $1.397-8.703$ & 0.007 \\
\hline Lung disease & 1.357 & $0.629-2.929$ & 0.437 & - & - & - \\
\hline Cerebrovascular disease & 1.561 & $0.449-5.434$ & 0.484 & - & - & - \\
\hline Malignant disease & 4.940 & $1.983-12.306$ & 0.001 & 9.275 & $3.181-27.040$ & 0.000 \\
\hline Kidney disease & 3.847 & $0.879-16.837$ & 0.074 & - & - & - \\
\hline Liver disease & 1.005 & $0.216-4.683$ & 0.995 & - & - & - \\
\hline Diabetes & 1.006 & $0.432-2.342$ & 0.989 & - & - & - \\
\hline Infectious disease & 2.242 & $1.085-4.634$ & 0.029 & 4.189 & $1.692-10.372$ & 0.002 \\
\hline Hypotension & 2.336 & $0.702-7.769$ & 0.166 & - & - & - \\
\hline Troponin-I & 1.045 & $0.958-1.141$ & 0.319 & - & - & - \\
\hline Main pulmonary artery involvement & 2.444 & $1.190-5.020$ & 0.015 & 3.032 & $1.283-7.162$ & 0.011 \\
\hline Right ventricular hypokinesia & 2.520 & $1.027-6.187$ & 0.044 & 1.997 & $0.696-5.735$ & 0.199 \\
\hline
\end{tabular}

PE: pulmonary embolism; OR: odds ratio; CI: confidence interval; BMI: body mass index.

the presence of VTE was 2-fold higher in patients with Clostridium difficile infection (CDI) than in those without $\mathrm{CDI}^{26}$. It has been also demonstrated that HIV infection and hepatitis virus infection are associated with an increased risk of $\mathrm{VTE}^{11,12}$. In a review of a primary care database of 11,557 cases of first-time PE or VTE, Clayton et al. ${ }^{27}$ reported that a preceding respiratory infection may increase the risk of PE or VTE by more than 2.5-folds for up to a year. A prospective study of 5,451 patients with ultrasound-confirmed DVT showed that beside known risk factors, osteoarthritis, pneumonia, sepsis, and other infectious diseases were present in more than 30\% of patientsl. In addition, in acutely ill, hospitalized, general medical patients, the presence of acute infectious diseases was significantly associated with an increased risk of VTE (relative risk, 1.47) ${ }^{24}$. Moreover, the epidemiologic study, a case control study involving patients with a first documented VTE and controls subjects, influenza vaccination during the previous 12 months reduced the risk of VTE by about $50 \%$ in those younger than 52 years and had a similar effect on DVT and $\mathrm{PE}^{28}$. Further, when heparin was routinely administered in hospital-admitted patients with underlying infectious disease, the occurrence of non-thromboembolic events was significantly lower in these patients with various infectious diseases than in control patients with infectious diseases ${ }^{22}$.

However, it is unclear whether the infection itself increases the risk of developing VTE or whether secondary problems, such as immobility caused by infection, increase the incidence of VTE. Although the mechanism was not elucidated here, there are possible explanations for the mechanism underlying infection and VTE. Acute infectious processes may cause endothelial injury, promoting the genesis of thrombosis in the venous system, which is usually much more vulnerable to stasis than is arterial blood. From experimental study, endothelial dysfunction in vein of healthy volunteer exposed to endotoxin may increase the risk of developing cardiovascular thromboticevent ${ }^{10}$.

Respiratory tract infection was the most common cause of infection in the present study. Cohoon et al. ${ }^{29}$ reported that genitourinary and lower respiratory tract infection was the most common infections in their study. They also reported a relatively higher risk of VTE in intra-abdominal infection and blood stream infection. This is a reason why patients with lower respiratory tract infection often undergo chest CT for evaluation of the disease. Thus, PE may be detected incidentally by chest CT. The increasing incidence of chest CT is often correlated with an increasing incidence of $\mathrm{PE}$, indicating that $\mathrm{PE}$ is incidentally detected by chest $\mathrm{CT}^{30,31}$. In this study, over two-thirds patients were diagnosed in chest CT, not embolism CT. It may indicate that PE is incidentally detected in clinical practice.

As expected, patients with PE combined with infectious conditions had a poor outcome, resulting in a higher mortality in these patients. This has not been reported previously. Other factors associated with an increased risk of mortality, such as older age, malignant disease, right ventricular dysfunction, and immobilization ${ }^{32,33}$, were similar to those identified in our study. Additionally, main pulmonary artery involvement is associated with a poor short-term outcome in patients with $\mathrm{PE}^{34}$.

This study has a several limitations. First, because of the study's retrospective design, infectious disease could not be 
clearly classified based on the medial record review and the exact incidence of infectious disease couldn't estimate from this study in all PE patients. Second, some proportion of patients with PE was incidentally detected by chest CT for evaluating respiratory tract infection. So, other infectious disease like intraabdominal and genitourinary tract infection may be underestimated. Third, most of patients had a severe underlying disease which may significantly contribute mortality in these patients. The adjustment of severe underlying disease needed to exact contribution of infectious disease to mortality in patients with PE.

\section{Authors' Contributions}

Conceptualization: Kim HC. Methodology: Lee GD, Kim HC. Formal analysis: Lee GD, Kim HC. Data curation: Lee GD, Kim HC. Software: Lee GD, Kim HC. Validation: Lee GD, Kim HC. Investigation: Ju S, Kim JY, Kim TH, Yoo JW, Lee SJ, Cho YJ, Jeong YY, Jeon KN, Lee JD. Writing - original draft preparation: Lee GD. Writing - review and editing: Lee GD, Kim HC. Approval of final manuscript: all authors.

\section{Conflicts of Interest}

No potential conflict of interest relevant to this article was reported.

\section{Funding}

No funding to declare.

\section{References}

1. Goldhaber SZ. Pulmonary embolism. Lancet 2004;363:1295305.

2. Heit JA. Epidemiology of venous thromboembolism. Nat Rev Cardiol 2015;12:464-74.

3. Hong J, Lee JH, Yhim HY, Choi WI, Bang SM, Lee H, et al. Incidence of venous thromboembolism in Korea from 2009 to 2013. PLoS One 2018;13:e0191897.

4. Jang MJ, Bang SM, Oh D. Incidence of venous thromboembolism in Korea: from the Health Insurance Review and Assessment Service database. J Thromb Haemost 2011;9:85-91.

5. Anderson FA Jr, Spencer FA. Risk factors for venous thromboembolism. Circulation 2003;107(23 Suppl 1):I9-16.

6. Heit JA. Risk factors for venous thromboembolism. Clin Chest Med 2003;24:1-12.

7. Smeeth L, Cook C, Thomas S, Hall AJ, Hubbard R, Vallance P. Risk of deep vein thrombosis and pulmonary embolism after acute infection in a community setting. Lancet 2006;367: 1075-9.

8. Grainge MJ, West J, Card TR. Venous thromboembolism during active disease and remission in inflammatory bowel disease: a cohort study. Lancet 2010;375:657-63.

9. Cervantes J, Rojas G. Virchow's Legacy: deep vein thrombosis and pulmonary embolism. World J Surg 2005;29 Suppl 1:S304.

10. Bhagat K, Moss R, Collier J, Vallance P. Endothelial "stunning" following a brief exposure to endotoxin: a mechanism to link infection and infarction? Cardiovasc Res 1996;32:822-9.

11. Copur AS, Smith PR, Gomez V, Bergman M, Homel P. HIV infection is a risk factor for venous thromboembolism. AIDS Patient Care STDS 2002;16:205-9.

12. Wijarnpreecha K, Thongprayoon C, Panjawatanan $\mathrm{P}$, Ungprasert P. Hepatitis C virus infection and risk of venous thromboembolism: a systematic review and meta-analysis. Ann Hepatol 2017;16:514-20.

13. Schimanski S, Linnemann B, Luxembourg B, Seifried E, Jilg W, Lindhoff-Last E, et al. Cytomegalovirus infection is associated with venous thromboembolism of immunocompetent adults: a case-control study. Ann Hematol 2012;91:597-604.

14. Paran Y, Halutz O, Swartzon M, Schein Y, Yeshurun D, Justo D. Venous thromboembolism and cytomegalovirus infection in immunocompetent adults. Isr Med Assoc J 2007;9:757-8.

15. Yildiz H, Zech F, Hainaut P. Venous thromboembolism associated with acute cytomegalovirus infection: epidemiology and predisposing conditions. Acta Clin Belg 2016;71:231-4.

16. Kiser KL, Badowski ME. Risk factors for venous thromboembolism in patients with human immunodeficiency virus infection. Pharmacotherapy 2010;30:1292-302.

17. Lozinguez O, Arnaud E, Belec L, Nicaud V, Alhenc-Gelas M, Fiessinger JN, et al. Demonstration of an association between Chlamydia pneumoniae infection and venous thromboembolic disease. Thromb Haemost 2000;83:887-91.

18. Koster T, Rosendaal FR, Lieuw-A-Len DD, Kroes AC, Emmerich JD, van Dissel JT. Chlamydia pneumoniae IgG seropositivity and risk of deep-vein thrombosis. Lancet 2000;355:16945.

19. Horan TC, Andrus M, Dudeck MA. CDC/NHSN surveillance definition of health care-associated infection and criteria for specific types of infections in the acute care setting. Am J Infect Control 2008;36:309-32.

20. Le Gal G, Righini M, Roy PM, Sanchez O, Aujesky D, Bounameaux $\mathrm{H}$, et al. Prediction of pulmonary embolism in the emergency department: the revised Geneva score. Ann Intern Med 2006;144:165-71.

21. Gardlund B. Fatal pulmonary embolism in hospitalized nonsurgical patients. Acta Med Scand 1985;218:417-21.

22. Gardlund B. Randomised, controlled trial of low-dose heparin for prevention of fatal pulmonary embolism in patients with infectious diseases. The Heparin Prophylaxis Study Group. Lancet 1996;347:1357-61. 
23. Belch JJ, Lowe GD, Ward AG, Forbes CD, Prentice CR. Prevention of deep vein thrombosis in medical patients by low-dose heparin. Scott Med J 1981;26:115-7.

24. Alikhan R, Cohen AT, Combe S, Samama MM, Desjardins L, Eldor A, et al. Risk factors for venous thromboembolism in hospitalized patients with acute medical illness: analysis of the MEDENOX Study. Arch Intern Med 2004;164:963-8.

25. Alikhan R, Cohen AT, Combe S, Samama MM, Desjardins L, Eldor A, et al. Prevention of venous thromboembolism in medical patients with enoxaparin: a subgroup analysis of the MEDENOX study. Blood Coagul Fibrinolysis 2003;14:341-6.

26. Bhandari S, Mohammed Abdul MK, Dhakal B, Kreuziger LB, Saeian K, Stein D. Increased rate of venous thromboembolism in hospitalized inflammatory bowel disease patients with Clostridium difficile infection. Inflamm Bowel Dis 2017; 23:1847-52.

27. Clayton TC, Gaskin M, Meade TW. Recent respiratory infection and risk of venous thromboembolism: case-control study through a general practice database. Int J Epidemiol 2011;40:819-27.

28. Zhu T, Carcaillon L, Martinez I, Cambou JP, Kyndt X, Guillot K, et al. Association of influenza vaccination with reduced risk of venous thromboembolism. Thromb Haemost 2009;102:125964.
29. Cohoon KP, Ashrani AA, Crusan DJ, Petterson TM, Bailey KR, Heit JA. Is infection an independent risk factor for venous thromboembolism? A population-based, case-control study. Am J Med 2018;131:307-16.

30. Winston CB, Wechsler RJ, Salazar AM, Kurtz AB, Spirn PW. Incidental pulmonary emboli detected at helical CT: effect on patient care. Radiology 1996;201:23-7.

31. Dentali F, Ageno W, Becattini C, Galli L, Gianni M, Riva N, et al. Prevalence and clinical history of incidental, asymptomatic pulmonary embolism: a meta-analysis. Thromb Res 2010;125:518-22.

32. Conget F, Otero R, Jimenez D, Marti D, Escobar C, Rodriguez $\mathrm{C}$, et al. Short-term clinical outcome after acute symptomatic pulmonary embolism. Thromb Haemost 2008;100:937-42.

33. Goldhaber SZ, Visani L, De Rosa M. Acute pulmonary embolism: clinical outcomes in the International Cooperative Pulmonary Embolism Registry (ICOPER). Lancet 1999;353: 1386-9.

34. Alonso Martinez JL, Anniccherico Sanchez FJ, Urbieta Echezarreta MA, Garcia IV, Alvaro JR. Central versus peripheral pulmonary embolism: analysis of the impact on the physiological parameters and long-term survival. N Am J Med Sci 2016;8:134-42. 